\title{
Ograniczanie obciążenia układu mięśniowo-szkieletowego przez zastosowanie wybranych urządzeń wspomagających przemieszczanie ładunków
}

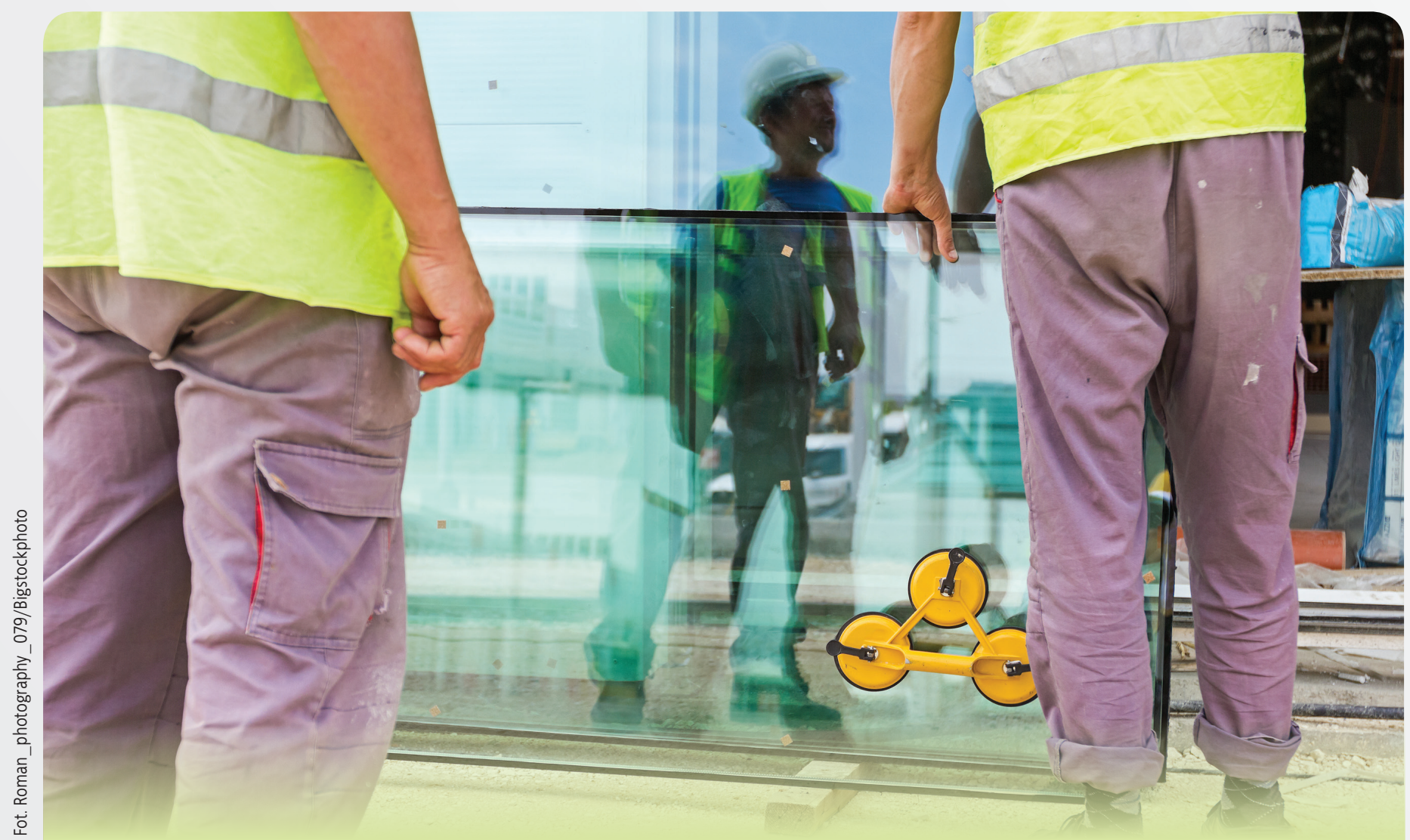

Dzięki zastosowaniu odpowiednich urządzeń wspomagających podnoszenie i przenoszenie ładunków można wyraźnie zmniejszyć obciążenie układu mięśniowo-szkieletowego. Jest to o tyle ważne, że z każdym rokiem przybywa pracowników po 55. roku życia, którzy dysponują mniejszą siłą mięśniową w porównaniu z osobami w młodszym wieku, a pracodawcy muszą dostosować warunki pracy osób starszych do ich możliwości psychofizycznych. W artykule przedstawiono wybrane urządzenia wspomagające podnoszenie i przenoszenie ładunków oraz zasady ich doboru z uwzględnieniem indywidualnych potrzeb i możliwości pracowników.

Słowa kluczowe: obciążenie układu mięśniowo-szkieletowego, urządzenia ręczne wspomagające transport/podnoszenie

Limiting the load on the musculoskeletal system by using selected devices supporting the movement of loads

By using appropriate lifting and carrying devices, the load on the musculoskeletal system can be significantly reduced. This is important because every year there are more and more employees over 55 who have less muscle strength compared to younger people, and employers have to adapt the working conditions of older people to their psychophysical capabilities. The article presents selected devices supporting lifting and carrying loads and the principles of their selection, taking into account the individual needs and capabilities of employees.

Keywords: load on the musculoskeletal system, manual handling devices 


\section{Wstęp}

Podczas czynności podnoszenia i przenoszenia ładunków największe obciążenie układu mięśniowo-szkieletowego wynika z występowania siły zewnętrznej - najczęściej masy ładunku. Tego typu obciążenia są zazwyczaj dobrze tolerowane przez osoby w wieku od 25 do 54 lat, które stanowią główną grupę pracowników w wieku produkcyjnym. Ze względu na fakt, że liczebność tej grupy do 2060 r. zmniejszy się o ok. 20\%, a jednocześnie zwiększy się grupa pracowników po 55. roku życia, należy wziąć pod uwagę konieczność ograniczenia obciążenia układu mięśniowo-szkieletowego i dostosowania obciążenia zewnętrznego do możliwości psychofizycznych starszych pracowników, np. przez zastosowanie urządzeń wspomagających, ponieważ - jak wiadomo - siła mięśniowa zmienia się wraz z wiekiem [1].

W przypadku ręcznych prac transportowych, obejmujących przemieszczanie ładunków, zarówno w polskich przepisach prawnych, jak i w dyrektywie UE [2], szczególny nacisk kładzie się na ograniczenie obciążenia pleców i kręgosłupa. Można to osiągnąć np. dzięki zmianie sposobu przenoszenia ładunków lub właśnie przez zastosowanie odpowiednich urządzeń wspomagających.

Przemieszczanie ładunków - a więc ich podnoszenie, przenoszenie i odkładanie - skutkuje zwiększeniem obciążenia mięśniowo-szkieletowego w obszarze prawie całego ciała człowieka. $Z$ drugiej strony, jak wskazują badania epidemiologiczne, coraz częściej występują dolegliwości i schorzenia w obszarze nie tylko tułowia [3] i kończyn górnych $[4,5]$, lecz także kończyn dolnych $[6,7]$. Powstawanie i rozwój tych dolegliwości i schorzeń wskazuje na przekroczenie możliwości fizycznych i wytrzymałościowych w poszczególnych obszarach układu mięśniowo-szkieletowego.

Ze względu na częste występowanie tego rodzaju problemów u pracowników w wieku powyżej 55 lat, a także z uwagi na wykorzystywanie przez nich sprzętu wspomagającego ręczny transport ładunków, wskazane jest określenie, czy i w jakim zakresie używanie go wpływa na obciążenie układu mięśniowo-szkieletowego podczas pracy. Celem artykułu jest omówienie tej tematyki na podstawie wyników badań własnych, dotyczących wpływu stosowania wybranych urządzeń wspomagających podnoszenie i przenoszenie ładunków na obciążenie układu mięśniowo-szkieletowego.

\section{Przemieszczanie ładunków}

Podnoszenie i przenoszenie ładunków przez pracowników w miejscu pracy polega na wykonaniu trzech czynności, określanych łącznie jako przemieszczenie. Są to:

- podnoszenie

- przenoszenie

- odkładanie.

Jeżeli wysokość miejsca, z którego podnoszony jest ładunek, i miejsca, na które jest odkładany, jest taka sama, to obciążenie układu mięśniowo-szkieletowego jest przy obu tych czynnościach zbliżone.

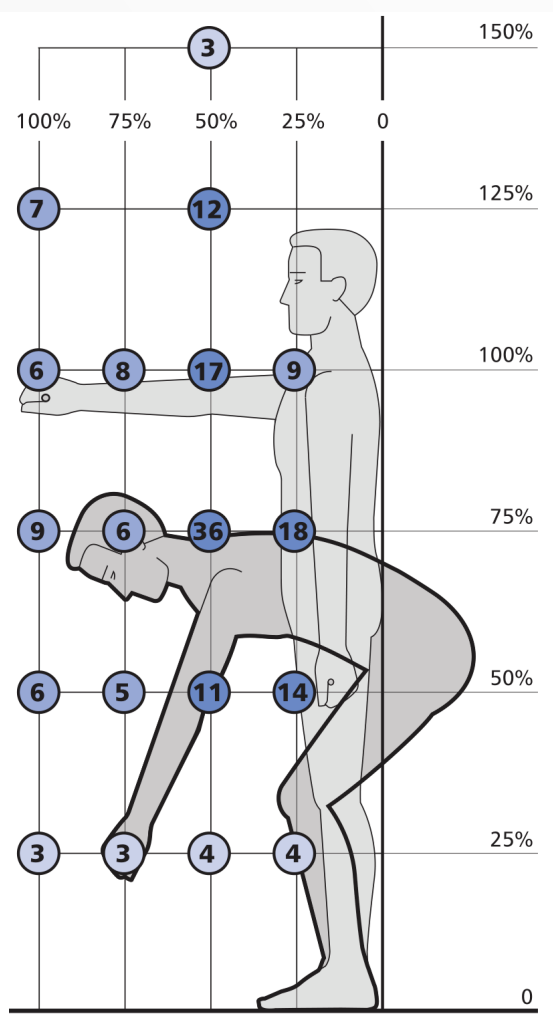

Rys. 1. Czas utrzymania pozycji ciała [min] w zależności od po zycji określonej w odniesieniu do maksymalnego zasięgu ramion [\%] (oś pozioma) oraz wysokości barków - stawu ramiennego [\%] (oś pionowa) [8]

Fig. 1. Time of maintaining the body position [min] depending on the position specified in relation to the maximum reach of the arms [\%] (horizontal axis) and shoulder height - the shoulder joint [\%] (vertical axis) [8]

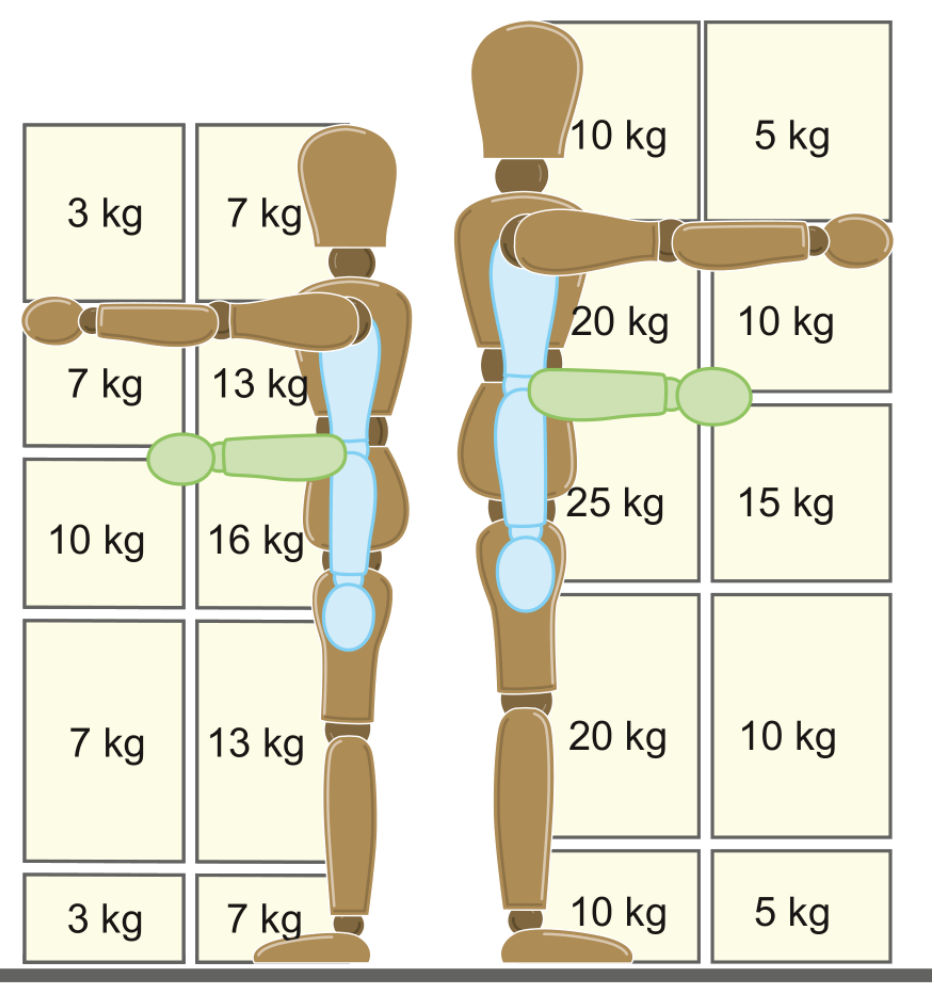

Rys. 2. Zalecana wartość masy ładunku dla kobiet i mężczyzn podczas podnoszenia tego ładunku w zależności od jego położenia względem poziomu barków, łokci, bioder, podudzi i podłogi [9]

Fig. 2. Recommended value of the weight of the load for women and men when lifting this load depending on its position in relation to the level of the shoulders, elbows, hips, lower legs and the floor [9]
Zdolność organizmu człowieka do podnoszenia ładunku zależy przede wszystkim od możliwości siłowych danej osoby, a w dłuższym okresie - także od jej układu oddechowego i układu krążenia. Dodatkowo niezbędne jest przyjęcie odpowiedniej pozycji na każdym etapie przemieszczania ładunku, co jest uwarunkowane zakresem ruchu w stawach. Ten z kolei ma wpływ np. na zasięg kończyn górnych i dolnych. Możliwości człowieka w zakresie podnoszenia zależą również od tego, na jakiej wysokości i w jakiej odległości od pracownika znajduje się ładunek. Zdolność do utrzymania konkretnej pozycji, określoną w minutach, omówiono m.in. w „Atlasie miar człowieka” [8] (rys. 1.).

Umiejętność utrzymania pozycji - np. pochylonej lub z ramionami wyciągniętymi do przodu lub do góry - ma wpływ na zdolność podnoszenia ładunków umieszczonych nisko lub wysoko. Jednak wysokość ich umiejscowienia (określona w centymetrach) względem podłoża nie jest właściwą miarą predyspozycji człowieka do wykonywania tego typu pracy, jest nią natomiast wysokość określona w odniesieniu do wysokości ciała pracownika - np. w sposób przedstawiony na rys. 2 .

Im wyżej lub im niżej w stosunku do poziomu bioder położony jest ładunek, tym mniejsza powinna być jego masa, aby uniknąć nadmiernego obciążenia układu mięśniowo-szkieletowego. To obciążenie podczas przenoszenia ładunku wynika przede wszystkim z jego masy i wymiarów oraz prędkości przenoszenia. Wraz ze zwiększaniem się tych trzech wielkości zwiększa się również obciążenie. . 
a)

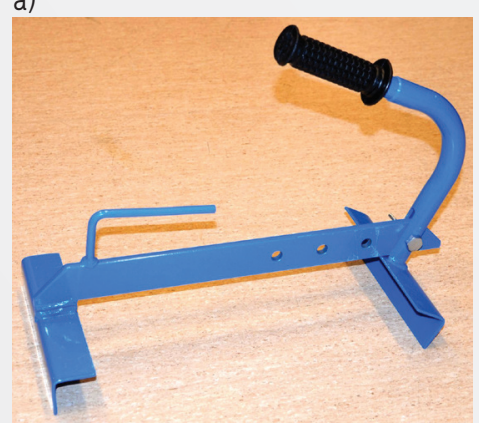

b)

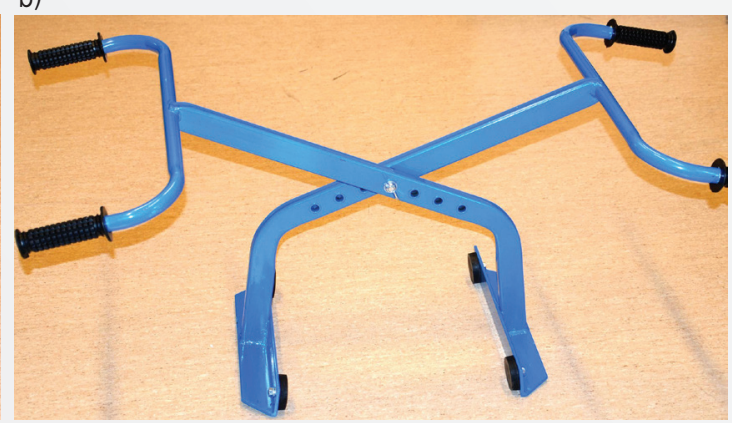

Fot. 1. Chwytak do płyt chodnikowych (a) i chwytak do krawężników (b) (fot. autora)

Photo 1. Grapple for: paving slabs (a) and curbs (b) (photo by the author)

\section{Charakterystyka wybranych do badań urządzeń wspomagających}

Urządzenia wspomagające podnoszenie i przenoszenie ładunków można podzielić na kilka głównych grup:

- proste urządzenia ręczne

- urządzenia do transportu osób (np. osób cho rych - nosze, wózki, dźwigi)

- ręczne urządzenia do przewożenia ładunków (np. taczki, wózki)

- urządzenia wspomagane elektrycznie, hydrau-

- urządzenia zwiększające możliwości siłowe pracownika/operatora (np. egzoszkielety).

Do oceny obciążenia wybrano urządzenia wspo-

magające, które spełniają następujące kryteria:

- umożliwiają ręczny transport ładunków (z zastosowaniem wspomagania lub bez)

- nie mają dodatkowego zasilania (elektrycznego, hydraulicznego, pneumatycznego lub innego)

- wspomaganie ogranicza się do czynności podnoszenia, przenoszenia i odkładania

- mogą być powszechnie stosowane i są łatwo dostępne

- mogą być użytkowane przez jednego lub dwóch pracowników innych ładunków niż te, do których zostały przeznaczone.

Ocenę obciążenia przeprowadzono podczas przemieszczania ładunków z zastosowaniem następujących urządzeń wspomagających:

- chwytaka do płyt chodnikowych

- chwytaka do krawężników

- uchwytów do płyt gipsowo-kartonowych.

Chwytak do płyt chodnikowych jest urządzeniem, które zapewnia łatwy chwyt i przeniesienie kształcalnych i o równoległych bokach (fot. 1a). Urządzenie to pozwala na podnoszenie i przenoszenie ładunku przy mniejszym obciążeniu układu mięśniowo-szkieletowego ze względu na:

- zastosowanie uchwytu pozwalającego na wykonywanie czynności podnoszenia z większej wysokości (przy mniejszym zgięciu w stawach kolanowych i/lub mniejszym pochyleniu tułowia)

- możliwość podnoszenia płyty lewą lub prawą ręką oraz oburącz licznie lub pneumatycznie (dźwigi, podnośniki)

- można je przystosować do przemieszczania

- uchwytów do szyb płyt chodnikowych lub innych ładunków nieod-
- zastosowanie w konstrukcji chwytaka mechanizmu dźwigni, pozwalającego na łatwe i pewne chwycenie ładunku podczas podnoszenia.

Chwytak do krawężników jest urządzeniem umożliwiającym podnoszenie i przenoszenie krawężników lub innych ładunków nieodkształcalnych i o równoległych bokach przez dwóch pracowników (fot. 1b). Urządzenie to pozwala na podnoszenie i przenoszenie z mniejszym obciążeniem układu mięśniowo-szkieletowego ze względu na:

- zastosowanie oddzielnie dla lewej i prawej kończyny uchwytów pozwalających na wykonywanie czynności podnoszenia z większej wysokości (przy mniejszym zgięciu w stawach kolanowych i/lub mniejszym pochyleniu tu łowia) oraz w bliższej odległości od środka ciężkości podnoszonego ładunku

- zastosowanie w konstrukcji chwytaka mechanizmu dźwigni, pozwalającego na łatwe i pewne chwycenie ładunku podczas podnoszenia.

Uchwyty do szyb wykorzystuje się do przenoszenia zarówno szyb, jak i innych przedmiotów o dużej powierzchni i niewielkiej grubości (fot. 2a). Podnoszenie i przenoszenie z użyciem tych urządzeń odbywa się przy mniejszym obciążeniu układu mięśniowo-szkieletowego ze względu na:

- mocowanie uchwytów na dowolnej wysokości do szyby - tę wysokość można indywidualnie dostosować do wysokości ciała pracownika (aby zmniejszyć zgięcie w stawach kolanowych i/lub pochylenie tułowia)

- przenoszenie szyby za rękojeść uchwytu urzą dzenia wspomagającego

- łatwe mocowanie uchwytu do szyby i odpinanie go.

Do urządzeń pomocniczych można zaliczyć również uchwyty do płyt gipsowo-kartonowych,

a)

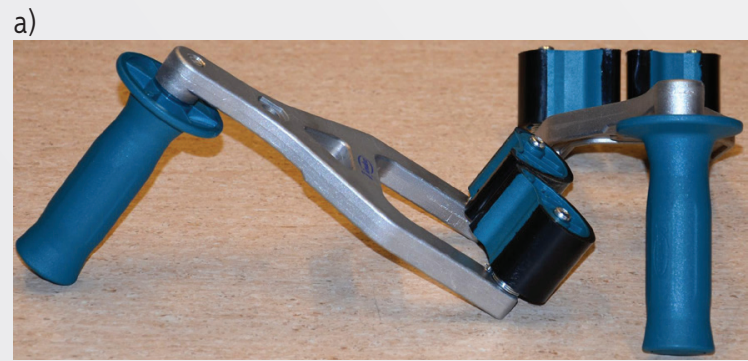

Fot. 2. Uchwyty do szyb (a) i płyt gipsowo-kartonowych (b) (fot. autora) Photo 2. Holders for glass (a) and plasterboard (b) (photo by the author)

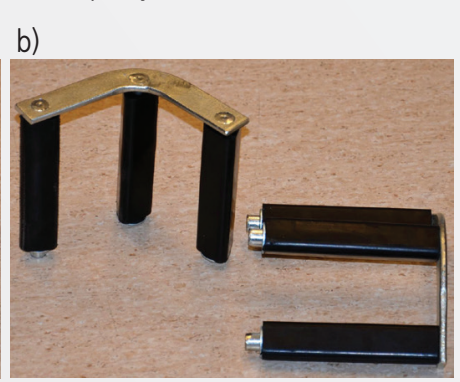

które nadają się do przenoszenia przedmiotów o dużej powierzchni i niewielkiej grubości, np. płyt wiórowych, paździerzowych czy OSB (fot. 2b). Uchwyty pozwalają na podnoszenie i przenoszenie przy mniejszym obciążeniu układu mięśniowo-szkieletowego ze względu na:

- mocowanie uchwytów do płyty gipsowo-kartonowej na dowolnej wysokości - można ją indywidualnie dostosować do wysokości ciała pracownika (aby zapewnić mniejsze zgięcie w stawach kolanowych i/lub mniejsze pochylenie tułowia)

- przenoszenie płyt za rękojeść uchwytu urzą dzenia wspomagającego

- łatwe mocowanie uchwytu do płyty i odczepianie go.

\section{Ocena obciążenia podczas przemieszczania ładunków}

Do oceny obciążenia układu mięśniowo-szkieletowego zastosowano metodę określoną w PN-EN 1005-2+A1:2010 [10], na podstawie której wyznaczana jest tzw. zalecana wartość graniczna masy, której ze względu na obciążenie pracownika nie należy przekraczać. Oblicza się ją na podstawie wzoru, uwzględniającego najważniejsze parametry mające wpływ na obciążenie podczas podnoszenia i odkładania ładunku:

- wysokość, z której jest podnoszony i na którą odkładany jest ładunek

odległość miejsca chwytu od osi ciała

- kąt skrętu podczas podnoszenia ładunku

- jakość chwytu ładunku

- częstość podnoszenia ładunku i czas wykonywania pracy związanej z podnoszeniem w czasie zmiany roboczej

- czynniki dodatkowe, takie jak praca zespołowa, czynności wykonywane jedną ręką lub oburącz oraz te związane z wysiłkiem fizycznym

Zalecana wartość graniczna masy pozwala na zakwalifikowanie analizowanej czynności do jednej z trzech stref:

- strefy zielonej, w której obciążenie jest małe (akceptowalne), a pozycje pracy są neutralne i nie ma potrzeby dokonywania zmian na stanowisku pracy

- strefy żółtej, w której obciążenie jest średnie (ak ceptowalne warunkowo), a pozycje pracy mogą mieć negatywny wpływ na układ mięśniowo -szkieletowy, w związku z czym należy wziąć pod uwagę możliwość wprowadzenia zmian na stanowisku pracy

b) 
Tabela. Zmiana obciążenia (oceniona zgodnie z PN-EN 1005-2+A1: 2010) wynikająca z zastosowania urządzenia wspomagającego podczas podnoszenia i odkładania ładunków

Table. Load change (assessed in accordance with PN-EN 1005-2 + A1: 2010) resulting from the use of a supporting device during lifting and depositing loads

\begin{tabular}{|l|c|c|c|}
\hline \multicolumn{1}{|c|}{$\begin{array}{c}\text { Urządzenie } \\
\text { wspomagające }\end{array}$} & Masa ładunku [kg] & $\begin{array}{c}\text { Masa ładunku } \\
\text { z urządzeniem [kg] }\end{array}$ & $\begin{array}{c}\text { Zmniejszenie (-) } \\
\text { lub zwiększenie (+) } \\
\text { obciążenia [\%] }\end{array}$ \\
\hline $\begin{array}{l}\text { Chwytak do płyt } \\
\text { chodnikowych }\end{array}$ & 10 & 12,51 & $+0,73$ \\
\cline { 2 - 4 } $\begin{array}{l}\text { Chwytak } \\
\text { do krawężników }\end{array}$ & 20 & 22,51 & $-9,37$ \\
\cline { 2 - 4 } & 10 & 13,88 & $+4,03$ \\
\cline { 2 - 4 } Uchwyt do szyb & 20 & 23,88 & $-10,53$ \\
\hline \multirow{2}{*}{$\begin{array}{l}\text { Uchwyt do płyt } \\
\text { gipsowo-kartonowych }\end{array}$} & 10 & 10,45 & $-16,42$ \\
\cline { 2 - 4 } & 20 & 20,45 & $-18,22$ \\
\hline
\end{tabular}

- $\quad$ strefy czerwonej, w której obciążenie jest duże lub bardzo duże (nieakceptowalne), a pozycje pracy przyjmowane przez pracownika nadmier nie obciążają układ mięśniowo-szkieletowy dlatego zmiany na stanowisku pracy powinny być przeprowadzone możliwie szybko.

\section{Wpływ urządzeń wspomagających na obciążenie układu mięśniowo-szkieletowego}

Wpływ wybranych urządzeń wspomagających analizowano na podstawie eksperymentu przepro wadzonego w CIOP-PIB. Zmiany obciążenia podczas podnoszenia i odkładania ładunków, wynikające z zastosowania urządzeń wspomagających i oszacowane na podstawie PN-EN 1005-2+A1:2010 przedstawiono w tabeli. Wartości ujemne świadczą o zmniejszeniu się obciążenia, a wartości dodatnie o jego zwiększeniu. Jak widać, obciążenie wzrosło w przypadku, gdy do przenoszenia ładunku o masie $10 \mathrm{~kg}$ użyto chwytaka do płyt chodnikowych lub chwytaka do krawężników. Wynika to z faktu zwiększenia masy ładunku o masę urządzenia wspomagającego. Należy jednak zwrócić uwagę, że wraz ze wzrostem masy ładunku masa urządzenia wspomagającego odgrywa coraz mniejszą rolę.

Najlepsze pod względem ograniczania obcią żenia układu mięśniowo-szkieletowego - przy przenoszeniu lżejszych $(10 \mathrm{~kg})$ i cięższych $(20 \mathrm{~kg})$ ładunków - okazały się uchwyty do płyt gipsowo -kartonowych oraz uchwyty do szyb.

\section{Dobór urządzeń wspomagających}

Urządzenie wspomagające musi być dopasowane do ładunku, który ma być przenoszony (wskazane jest stosowanie specjalistycznych urzą dzeń przeznaczonych do konkretnych ładunków) W jego doborze należy uwzględnić:

- parametry i charakterystykę ładunku - masę wymiary, twardość, podatność na odkształcenie, położenie środka ciężkości, zawartość (lepkość, płynność, sypkość, środki niebezpieczne itp.) uchwyty lub sposób chwytania ładunku

- warunki otoczenia miejsca przemieszczania - podłoże (twardość, gładkość, nachylenie, schody itp.), ograniczenie przestrzeni pracy (wysokość i szerokość miejsca podnoszenia i odkładania, drogi przemieszczania) tempe- raturę, wilgotność, prędkość ruchu powietrza w pomieszczeniu lub w miejscu na otwartej przestrzeni

- możliwość zasilania (elektrycznego, pneumatycznego lub hydraulicznego).

Ponadto w celu zmniejszenia obciążenia układu mięśniowo-szkieletowego należy:

- czynności ręcznego podnoszenia i przeno szenia zastępować przewożeniem ładunków z zastosowaniem wózków i innych urządzeń wyposażonych w kółka albo z użyciem spe cjalistycznego sprzętu (np. dźwigów, suwnic) przeznaczonego do przemieszczania ładunków; - stosować urządzenia wspomagane elektrycznie pneumatycznie lub hydraulicznie w celu ogra niczenia obciążenia podczas przemieszczania ładunków umożliwiają wykonanie danej czynności zespo łowo (np. chwytak do krawężników); pozwalają na zmianę wysokości podnoszenia ładunku (np. chwytak do płyt chodnikowych lub krawężników); ułatwiają chwytanie takich ładunków, jak płyty gipsowo-kartonowe lub szyby; umożliwiają przenoszenie ładunków (niezależnie od ich wielkości) w pozycji wyprostowanej; dają się zaadaptować do przenoszenia innych ładunków (nieuwzględnionych w opisie przeznaczenia).

\section{Podsumowanie}

Zastosowanie prostych urządzeń wspoma gających pozwala ograniczyć obciążenie układu mięśniowo-szkieletowego - np. dzięki zmianie wysokości, z której jest podnoszony i na którą odkładany jest ładunek, oraz dzięki poręcznemu uchwytowi, gwarantującemu pewny chwyt i ułatwiającemu przemieszczanie ładunku. Jednakże takie dodatkowe urządzenia powodują, że zwiększa się masa podnoszonego i przenoszonego ładunku. W przypadku ocenianych urządzeń zwiększenie masy wynosiło od ok. 0,5 kg do ponad 3,5 kg. Ma to znaczenie zwłaszcza wtedy, gdy masa podnoszonego ładunku jest niewielka. Ocena obciążenia przeprowadzona według metody i kryteriów zawartych w PN-EN 1005-2+A1:2010 pokazała, że obciążenie podczas podnoszenia i przenoszenia ładunków o masie 10 i 20 kg zmniejszyło się - w zależności od zastosowanego urządzenia wspomagającego - od ponad $9 \%$ do prawie $20 \%$. Zmniejszenie obciążenia wynika przede wszystkim
- stosować urządzenia wspomagające, które z faktu zmiany wysokości uchwytów do przenoszenia oraz ze zwiększenia pewności chwytu wskutek zastosowania uchwytów, np. w przypadku przenoszenia płyt.

Pracodawca i służba bhp powinni jednak uwzględnić masę tych urządzeń przy określaniu dopuszczalnej masy podnoszonego ładunku, która musi być zgodna z polskim prawem [11]

\section{BIBLIOGRAFIA}

[1] TOKARSKI, T., ROMAN-LIU, D., KAMIŃSKA, J., 2012. The influence of age and type of force on muscle strength capabilities in women. International Journal of Occupational Safety and Ergonomics (JOSE). 2012, 18(1): 47-57.

[2] Dyrektywa Rady z dnia 29 maja 1990 r. w sprawie minimalnych wymagań dotyczących ochrony zdrowia i bezpieczeństwa podczas ręcznego przemieszczania ciężarów w przypadku możliwości wystąpienia zagrożenia, zwłaszcza urazów kręgosłupa pracowników (90/269/EWG - czwarta szczegółowa dyrektywa w rozumieniu art. 16 ust. 1 dyrektywy 89/391/EWG) (Dz.Urz. L 156 z 21.06.1990 r., s. 9-13). [3] GOVINDU, N.K., BABSKI-REEVES, K. Effects of personal, psychosocial and occupational factors on low back pain severity in workers. International Journal of Industrial Ergonomics. 2014, 44: 335-341. [4] COLOMBINI, D., OCCHIPINTI, E. Preventing upper limb work-related musculoskeletal disorders (UL-WMSDS): New approaches in job (re)design and current trends in standardization. Appl. Ergon. 2006, 37: 441-450.

[5] BUCKLE, P.W., DEVEREUX, J.J. The nature of work-related neck and upper limb musculoskeletal disorders. App. Ergon. 2002, 33: 207-217.

[6] REID, C.R., et al. Occupational postural activity and lower extremity discomfort: A review. International Journal of Industrial Ergonomics. 2010, 40: 247-256.

[7] BHAT, W., et al. Lower limb trauma and posttraumatic stress disorder: A single UK trauma unit's experience. Journal of Plastic, Reconstructive \& Aesthetic Surgery. 2014, 67: 555-560

[8] GEDLICZKA, A. Atlas miar człowieka. Warszawa: CIOP, 2001.

[9] Manual handling at work. A brief guide. http:// www.hse.gov.uk/pubns/indg143.pdf (dostęp: 17.03.2021 r.).

[10] PN-EN 1005-2+A1:2010 Bezpieczeństwo maszyn - Możliwości fizyczne człowieka - Część 2: Ręczne przemieszczanie maszyn i ich części.

[11] Rozporządzenie Ministra Pracy i Polityki Społecznej z dnia 14 marca 2000 r. w sprawie bezpieczeństwa i higieny pracy przy ręcznych pracach transportowych (t.j. Dz.U. z 2018 r., poz. 1139).

Publikacja opracowana na podstawie wyników III etapu programu wieloletniego "Poprawa bezpieczeństwa i warunków pracy", finansowanego w latach 2014-2016 w zakresie zadań służb państwowych ze środków Ministerstwa Rodziny, Pracy i Polityki Społecznej.

Koordynator programu: Centralny Instytut Ochrony Pracy - Państwowy Instytut Badawczy. 